\title{
Ecology of curlleaf mahogany in western and central Nev- ada: community and population structure
}

\author{
B.W. SCHULTZ, P.T. TUELLER, AND R.J. TAUSCH
}

\section{Abstract}

Curlleaf mahogany is an important browse species for mule deer in the mountain brush zone of the Intermountain Weat. Past research on increasing browse avallability of curlleaf mahogany has been inconclusive. This appeared to be directly related to limited understanding of community and population structure and dynamics. To obtain information on the community and population structure of curlleaf mahogany we sampled 25, $30 \times 30-\mathrm{m}$ macroplots in western and central Nevada. Data on mahogany denaity, maturity class structure, size, ages, and population growth rates were obtained. Understory cover and composition and percent rock, bare ground, and litter were also recorded. Mahogany density in central Nevada was one-haif that in western Nevada, but mahogany cover and total cover were significantly $(P \leq 0.05)$ greater. Maturity class distribution in central Nevada was heavily skewed towards large mature mahogany, sugeesting an older population dominated by fewer large individuals. This dominance resulted in significantly $(P \leq 0.05)$ lower population and relative growth rates and the necessity of canopy gaps for the survival of young mahogany. Range improvement of mature mahogany stands dominated by large individuals will require the removal of the mature and over mature individuals so that young forage producing plants are released from intraspecific competition.

Key Words: curlleaf mahogany, Cercocarpus ledifolites, population structure, community structure, size-age-denaity relationships, overstory-understory relationships

Curlleaf mahogany (Cercocarpus ledifolius) is a little studied, evergreen xerophyte (Daubenmire 1959). The species is often found in the mountain brush zone (Scheldt and Tisdale 1970) of the Intermountain West. Although it is an important browse species for mule deer (Odocoileus hemionus), curlleaf mahogany is not highly desired by domestic livestock (Smith and Hubbard 1954, Sampson and Jespersen 1963). Excessive browsing and an erect growth form often lead to stands that provide little available browse (Mitchell 1951).

Treatments to increase browse availability have been costly, and largely unsuccessful (Phillips 1970, Thompson 1970, Plummer 1974, Ormiston 1978, Austin and Urness 1980). This is due, at least in part, to a lack of information on stand and population structure and the resulting influences of intraspecific competition. Competition eventually occurs as the individuals present in a population increase in number and size. Indicators of competition are reproduction that is poor or absent (Long and Turner 1975, Oliver 1981), closure of the crown canopy (Assman 1970), and the reduction of growth rates in individual plants relative to their potential (Long and Smith 1984). The objective of this study was to measure stands and individuals of curlleaf mahogany to obtain demographic data useful in quantifying stand structure and population dynamics.

\section{Study Site Descriptions}

Curlleaf mahogany communities were studied in 25 macroplots

\footnotetext{
Authors are research assistant, professor, and assistant professor, Department of Range, Wildlife and Forestry, University of Nevada, Reno 98512 . The senior author is currently with the Bureau of Land Management, Ely, Nevada 89301.
}

on 3 mountain ranges in western and central Nevada. Nine western Nevada macroplots were located on Peavine Mountain and 4 in the Carson Range. Twelve central Nevada macroplots were located in the Shoshone Range. Sampling occurred during May through August of 1985.

Elevation of mahogany on Peavine Mountain varies from 1,520 to $2,485 \mathrm{~m}$. Annual precipitation averages $36-41 \mathrm{~cm}$ and occurs mostly as snow. The average frost-free period is $50-80$ days. Curleaf mahogany stands are largely restricted to the Ticino gravelly fine sandy loam (SCS 1983). Effective rooting depth is $51-103 \mathrm{~cm}$. Scattered mahogany occur near $1,890 \mathrm{~m}$ on west, east, and north aspects, but dominant stands are present only above $1,980 \mathrm{~m}$. Mahogany stands on south facing slopes are found above $2,260 \mathrm{~m}$. Stands vary in size from several to hundreds of hectares. Smaller stands are most common along rocky ridges, and as islands within low sagebrush (Artemisia arbuscula) communities. Large stands occur on hillsides and are commonly surrounded by mountain big sagebrush (Artemisia tridentata vaseyana).

Sampling in the Carson Range occurred between 1,550 and $1,890 \mathrm{~m}$. The mixed conifer zone generally occurs above 1,900 to $2,000 \mathrm{~m}$, with intermixed or isolated mahogany stands as high as $2,590 \mathrm{~m}$, but only on southerly aspects or rocky sites. Conifer species completely replace mahogany on north facing slopes above $2,200 \mathrm{~m}$. Sampled communities were in the 36 to $51-\mathrm{cm}$ precipitation zone with most of it occurring as snow during the winter months. Average frost free period is $\mathbf{5 0}$ to 80 days. Soils supporting mountain mahogany stands are Duckhill stony loam, Apmat gravelly sandy loam, and the Fraval-Hirschdale-Jumbo association (SCS 1983). Effective rooting depth varies from 20 to over $154 \mathrm{~cm}$.

Mahogany in the Shoshone Range occurs as low as 2,150 $\mathrm{m}$ on north aspects, but, sizeable stands are rarely present below 2,380 $\mathrm{m}$. Southern aspects have few mahogany stands below $2,600 \mathrm{~m}$. All other aspects have abundant mahogany stands between 2,450 and $3,050 \mathrm{~m}$. Limber pine (Pinus flexilus) is a common associate above $2,900 \mathrm{~m}$. Annual precipitation averages 41 to $51 \mathrm{~cm}$. Unlike western Nevada, heaviest precipitation occurs during the early part of the growing season, March through June (Houghton et al. 1975), and summer rainfall is also more abundant. Frost free period is 30 to 50 days. Stands tend to be restricted to the Foxmount soil series; specifically Foxmount gravelly loam (Carol Jett, personal communication). These are well drained, moderately permeable soils with an effective rooting depth of 51 to $103 \mathrm{~cm}$ and an 18 to $38 \mathrm{~cm}$ mollic epipedon.

\section{Methods}

\section{Field Sampling}

An initial field reconnaissance near Reno, Nevada indicated that mahogany stands are comprised of individuals that can be categorized in 6 maturity classes. These maturity classes are: reproduction, juvenile, immature, young-mature, and overmature-decadent (Table 1).

Sampling occurred in $30 \times 30-\mathrm{m}$ macroplots, each having at least one young-mature individual (Table 1) and placed as close as possible to a cardinal aspect. Ecotones with adjacent plant communities were avoided. Upper, middle, and lower portions of the 
Table 1. Mountain mahocany maturity clasues developed from a reconmaireance of mahogany stands near Reno, NV.

1. Reproduction

2. Juvenile

3. Immature

4. Young-mature

5. Mature young plants; 2 to $7 \mathrm{~mm}$ basal diameter; smooth bark; plants may be up to $30 \mathrm{~cm}$ in height.

young plants greater than $7 \mathrm{~mm}$ basal diameter; smooth bark; plants to $60 \mathrm{~cm}$ tall.

young plants greater than $1.25 \mathrm{~cm}$ basal diameter; smooth bark; plants to $1.5 \mathrm{~m}$ tall.

cracked bark; $1.5-3.0 \mathrm{~m}$ tall; crown broadened; may be multistemmed from base; not suppressed by adjacent larger mahogany plants.

cracked bark; wide full crown; few dead branches; may have several stems from base; may be suppressed by adjacent larger mahogany plants; greater than $3 \mathrm{~m}$ tall.

cracked bark; may be multistemmed; numerous dead branches; may be greater than $3 \mathrm{~m}$ tall; frequently suppressed by adjacent larger mahogany plants.
Understory species cover (\%) was summarized by plot and for the entire macroplot and averaged for each study area. Percent litter, bare ground, and rock were determined by the same process.

Growth ring counts and measurements were made along 2 sanded radii on each cross section. Growth rings were identified by a single row of larger vessels in the spring wood. Modifications of a technique using acetic acid and zinc oxide (Parker et al. 1976) were used to enhance the contrast between early and late wood in each annual ring. Time and funding constraints did not allow us to determine if false rings were present. A reference chronology was not available for cross dating.

Yearly growth increments were measured to the nearest $0.01 \mathrm{~mm}$ for the $\mathbf{1 0}$ years before harvest using a Craighead-Douglas dendrochronograph and a binocular microscope. Age and ring width data for each radii were averaged for each cross section. Ringwidth data were used to calculate the stem area increment $\left(\mathrm{cm}^{2} / 10\right.$ years) of each cross section and were summarized by maturity class, macroplot, and study area.

Past population growth rates were estimated from the relationship between the natural logarithms of cumulative stand density and the ages of the surviving stand members (Harper 1977). Because it was impossible to determine the age of every mahogany in each macroplot, a modified version of these growth curves was used. Mean maturity class age was substituted for the ages of the individual survivors. The resulting curve for each location displayed the relationship between cumulative density (In) and the approximate ages of the survivors by maturity class. Mature and overmature mahogany were combined in each study area because of their similar mean age.

Differences in mean understory cover, mean mahagony cover, mean mahogany crown diameter and crown height, mahogany crown volume, and mean ring widths between study areas were tested for significance $(P \leq 0.05)$ with the students $t$-test (Steel and Torrie 1980). The Kolmogorov-Smirnov test (Steel and Torrie 1980) was used to compare study areas for their relative distribution of mahogany density among the maturity classes.

\section{Results and Discussion}

\section{Cover}

Largest mahogany plants were generally found on north and east aspects, and smallest plants on south and west aspects. Stand size ranged from less than one to over hundreds of hectares. Smallest stands occurred along rocky ridge lines, and largest stands on sloping mountain sides and in bowls below the mountain crest.

Average total vegetation cover was highest on the Shoshone Range (Table 2) with half of the macroplots reaching $100 \%$ vegetation cover. Macroplots in western Nevada had substantially less total cover than macroplots in central Nevada. Mahogany cover (\%) in the Shoshone Range averaged over $20 \%$ greater than in western Nevada. Differences in mahogany cover between Peavine Mountain and the Carson Range were small. However, relative mahogany cover was virtually identical in each population.

Mature and/ or young-mature mahogany accounted for most of the mahogany cover in each study area. Their cover contribution was substantially greater than their relative proportion (\%) of the population density (Figs. 1 and 2). Overmature mahogany provided little cover (Fig. 1). Immature and younger mahogany also provided very little cover, even at high densities (Figs. 1 and 2).

Conifer species had higher cover values in the Shoshone Range than in western Nevada, but their actual contribution was small. Pinyon pine (Pinus monophylla) was the most frequent tree, but limber pine, when present, provided substantially more cover. Pinyon seedlings were common in all but the highest elevation macroplots.

Average understory cover was almost identical for each study 
Table 2. Mean vezetation and soll surface characteriatics for 3 mahogany communities in Nevada.

\begin{tabular}{|c|c|c|c|c|c|c|c|c|c|c|}
\hline \multirow[b]{2}{*}{ Study area } & \multicolumn{10}{|c|}{ Cover' } \\
\hline & Shrub & Grass & Forb & $\begin{array}{l}\text { Under- } \\
\text { story }\end{array}$ & $\begin{array}{l}\text { Curlleaf } \\
\text { mahogany }\end{array}$ & $\begin{array}{c}\text { Total } \\
\text { vegetative }\end{array}$ & $\begin{array}{c}\text { Relative } \\
\text { mahogany }\end{array}$ & Litter & Rock & Bareground \\
\hline $\begin{array}{l}\text { Peavine Mountain } \\
\text { Carson Range } \\
\text { Shoshone Range }\end{array}$ & $\begin{array}{c}8 \mathrm{a}^{1} \\
7 \mathrm{ab} \\
11 \mathrm{~b}\end{array}$ & $\begin{array}{l}1 \mathrm{a} \\
7 \mathrm{~b} \\
2 \mathrm{a}\end{array}$ & $\begin{array}{l}5 a \\
1 b \\
2 b\end{array}$ & $\begin{array}{l}14 a \\
15 a \\
15 a\end{array}$ & $\begin{array}{l}56 a \\
54 a \\
79 b\end{array}$ & $\begin{array}{l}70 \mathrm{a} \\
68 \mathrm{a} \\
98 \mathrm{~b}\end{array}$ & $\begin{array}{l}80 \mathrm{a} \\
78 \mathrm{a} \\
78 \mathrm{a}\end{array}$ & $\begin{array}{l}67 a \\
61 a \\
76 b\end{array}$ & $\begin{array}{l}23 a \\
35 a \\
14 b\end{array}$ & $\begin{array}{r}10 a \\
4 a \\
10 a\end{array}$ \\
\hline
\end{tabular}

IMeans in the same column followed by the same letter do not differ significantly at the .05 level.

area, but varied widely among the macroplots ( 2 to $37 \%)$. The percent contribution of shrub, grass, and forb species also varied between study areas. Shrub cover was highest in the Shoshone Range and grass cover highest in the Carson Range. Forb cover was highest on the Peavine Mountain (Table 2).

Litter cover (\%) was abundant in all areas, but had substantially higher values in the Shoshone Range (Table 2), where litter depth was also greater. Surface rock was abundant in western Nevada, particularly in the Carson Range. Bare ground (\%) was low in each study area.

\section{Mahogany Density}

Peavine Mountain had the highest mahogany density and the

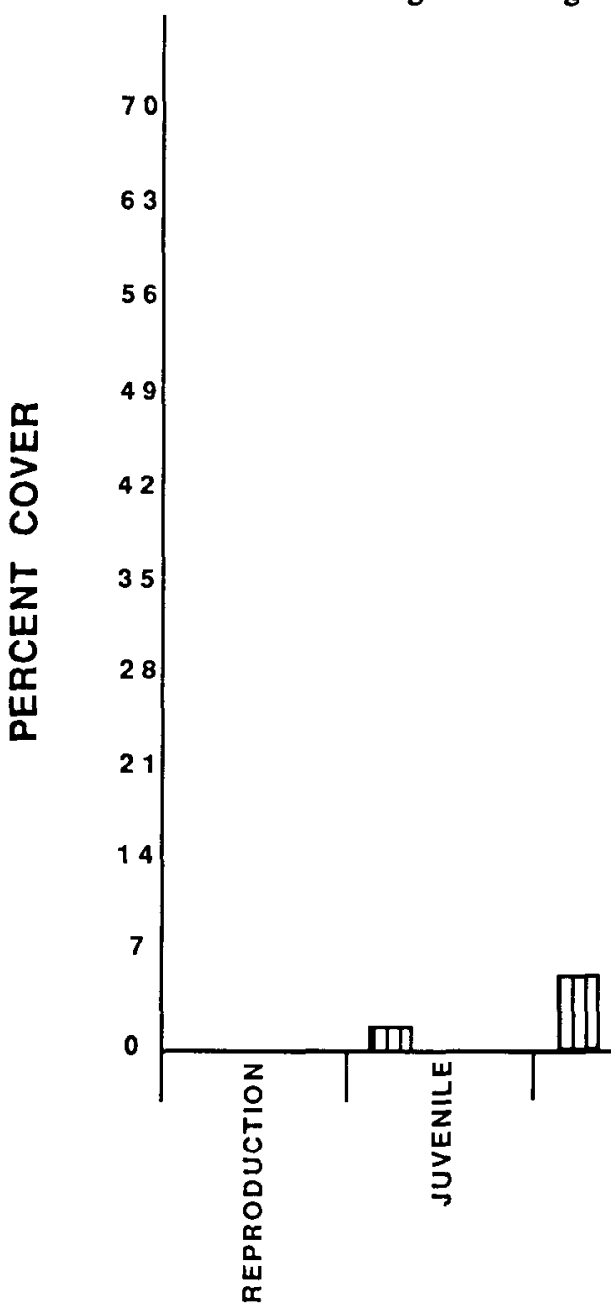

Shoshone Range the lowest (Fig. 3). Mahogany density in individual macroplots varied from 25 to 267 mahogany/macroplot (278 to 2,968 mahogany/ha). Mahogany density in this study was substantially greater than that observed in Utah by Davis (1976) but less than in Montana (Duncan 1975). Few mahogany seedlings were present in macroplots on Peavine Mountain and none were observed in the Carson Range. Abundant seedlings $\left(2.0 / \mathrm{m}^{2}\right)$ were present in all macroplots in the Shoshone Range.

\section{Maturity Class Distribution}

Maturity class distribution on Peavine Mountain was significantly different $(P \leq 0.05)$ than maturity class distribution on the Carson and Shoshone Ranges (Fig. 2) based on the Kolmogorov-

\section{MATURITY CLASS}

Fig. 1. Average curlleaf mahogany cover for each maturity class at 3 sites in Nevada. Maturity class designations are defined in Table 1. 


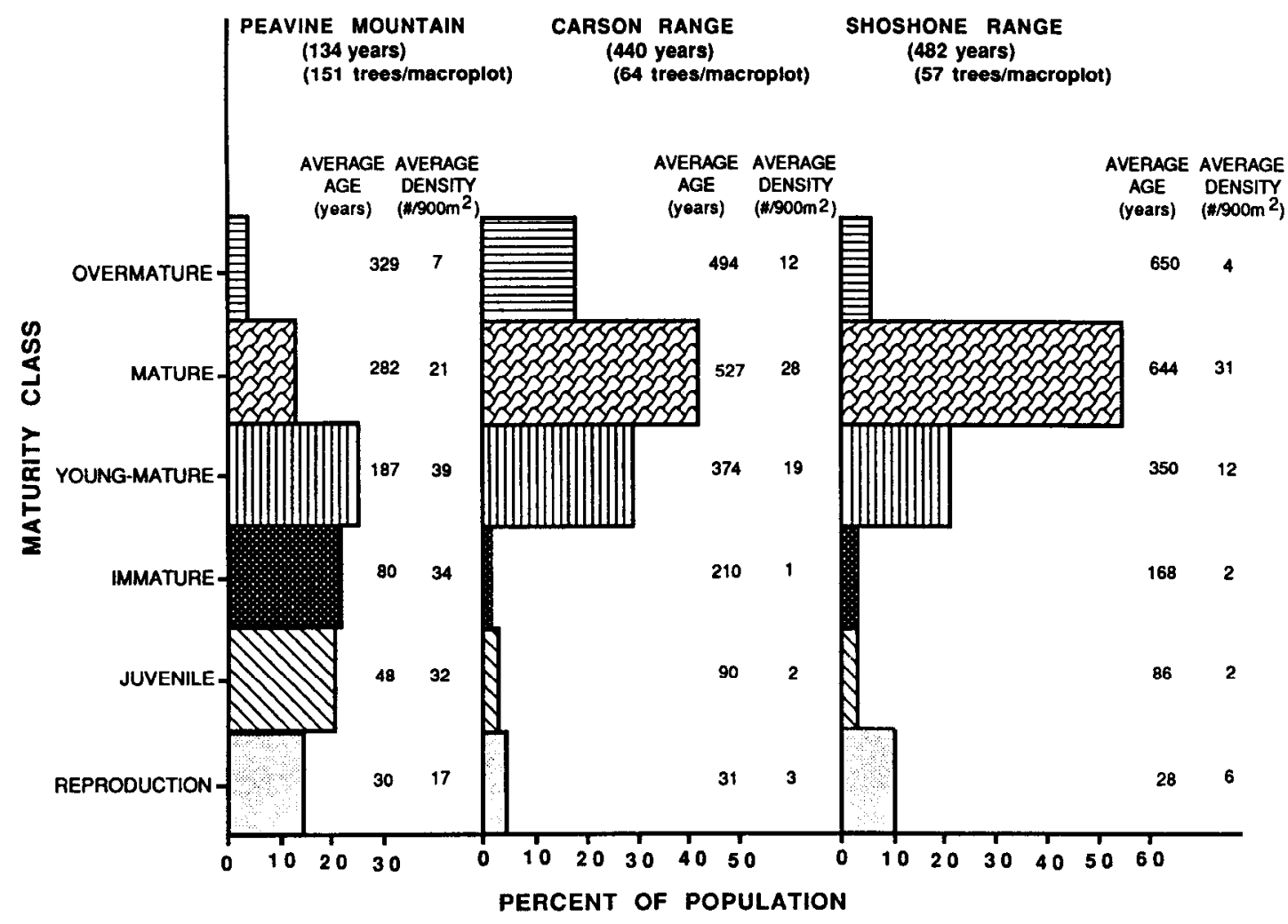

Fig. 2. Average curlleaf mahogany age, density, and relative contribution to total density for each maturity class at 3 sites in Nevada. Maturity class dedgnations are defined in Table 1.

Smirnov tests. Maturity class distribution did not differ significantly $(P \leq 0.05)$ between mahogany populations in the Carson and Shoshone Ranges.

On Peavine Mountain no one maturity class dominated the population structure (Fig. 2). Reproduction, juvenile, immature, and young-mature mahogany had significantly $(P \leq 0.05)$ higher densities on Peavine Mountain than the other 2 locations. The relative density of the juvenile and immature maturity classes were

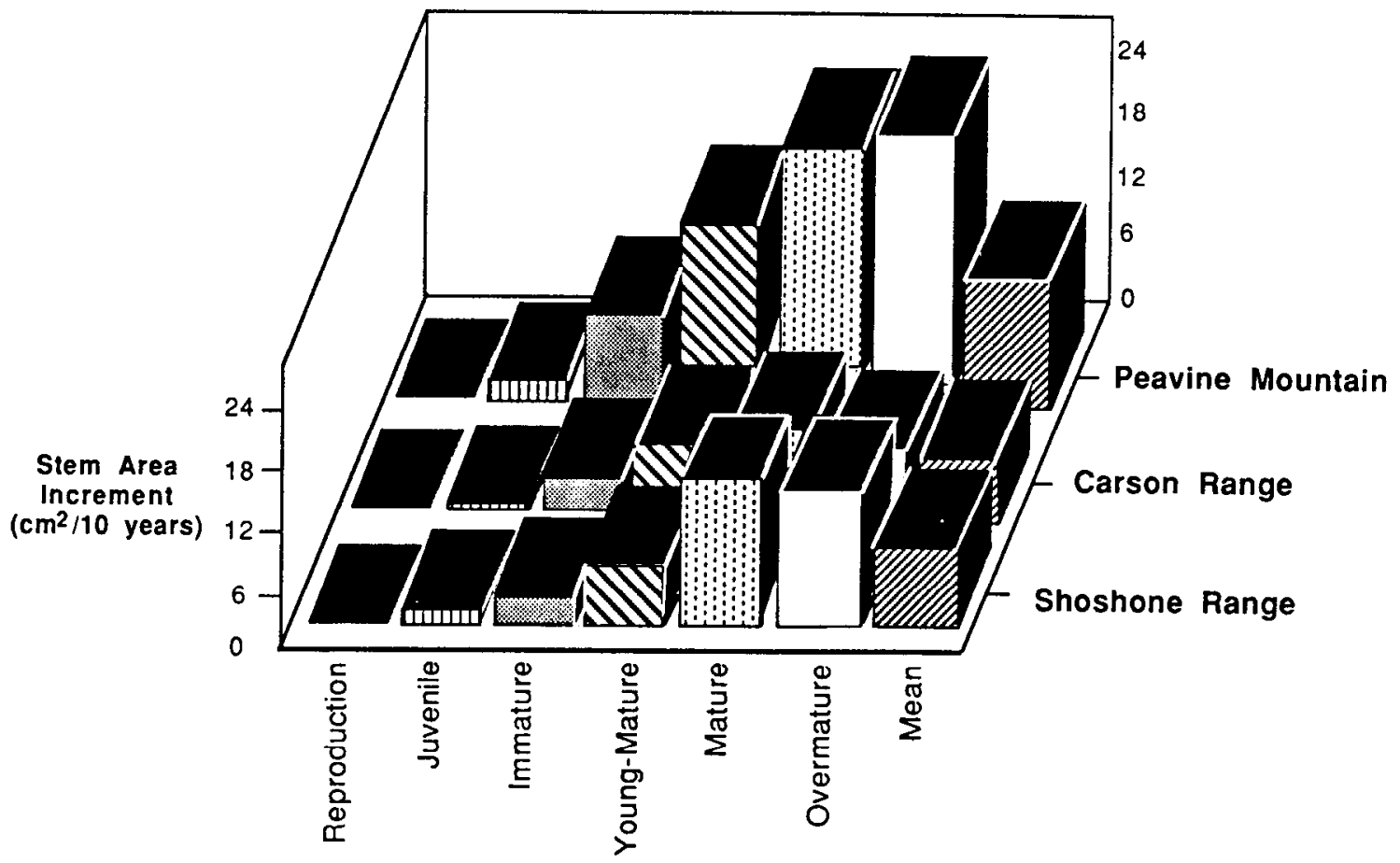

MATURITY CLASS

Fig. 3. Average curlleaf mahogany stem area increment values in each maturity class at 3 sites in Nevada. Maturity class designations are defined Table 1. 
Table 3. Mean mahogany helpht and erown diameter in each maturity elaed for 3 mahogany populations in Nevada.

\begin{tabular}{|c|c|c|c|c|c|c|}
\hline \multirow[b]{2}{*}{ Maturity class } & \multicolumn{3}{|c|}{ Height } & \multicolumn{3}{|c|}{ Crown Diameter } \\
\hline & Peavine Mountain & Carson Range & Shoshone Range & Peavine Mountain & Carson Range & Shoshone Range \\
\hline & & $-\mathrm{dm}$ & & & $\mathrm{dm}$ & \\
\hline $\begin{array}{l}\text { Reproduction } \\
\text { Juvenile } \\
\text { Immature } \\
\text { Young-mature } \\
\text { Mature } \\
\text { Overmature } \\
\text { Mean }\end{array}$ & $\begin{array}{r}2.6 a^{1} \\
6.3 a \\
11.3 a \\
21.1 a \\
25.2 a \\
22.4 a \\
16.4 a\end{array}$ & $\begin{array}{l}3.2 \mathrm{a} \\
6.1 \mathrm{a} \\
14.7 \mathrm{a} \\
29.9 \mathrm{ab} \\
35.9 \mathrm{a} \\
27.7 \mathrm{a} \\
31.4 \mathrm{~b}\end{array}$ & $\begin{array}{r}1.6 \mathrm{~b} \\
5.2 \mathrm{a} \\
10.7 \mathrm{a} \\
31.6 \mathrm{~b} \\
45.6 \mathrm{~b} \\
39.5 \mathrm{~b} \\
37.8 \mathrm{~b}\end{array}$ & $\begin{array}{r}5.8 \mathrm{a} \\
11.1 \mathrm{a} \\
19.0 \mathrm{a} \\
37.1 \mathrm{a} \\
53.5 \mathrm{a} \\
39.1 \mathrm{a} \\
28.8 \mathrm{a}\end{array}$ & $\begin{array}{c}4.5 \mathrm{ab} \\
10.8 \mathrm{ab} \\
16.6 \mathrm{~b} \\
42.9 \mathrm{a} \\
55.9 \mathrm{a} \\
35.0 \mathrm{ab} \\
43.6 \mathrm{~b}\end{array}$ & $\begin{array}{l}2.5 b \\
8.6 \mathrm{~b} \\
15.6 \mathrm{ab} \\
37.4 \mathrm{a} \\
73.1 \mathrm{~b} \\
54.0 \mathrm{~b} \\
57.4 \mathrm{~b}\end{array}$ \\
\hline
\end{tabular}

IMeans within the same row and dimensional parameter followed by the same letter do not vary significantly at the 0.05 level.

also higher on Peavine Mountain (Fig. 2). The general lack of crown closure on Peavine Mountain (Table 2) has permitted a steady increase in density since establishment of the oldest individuals (Fig. 3). This includes high survival of juvenile and immature mahogany during the past 100 years.

Reproduction mahogany were sparse, and their survival and recruitment into juvenile class appears to have been low on both the Carson and Shoshone Ranges (Figs. 2 and 3). Of the 16 macroplots sampled in the Carson and Shoshone Ranges 15 had fewer juvenile than reproduction mahogany, and 13 had fewer immature than reproduction plants. Juvenile mahogany, once established, appear to be recruited into the immature class with little mortality.

Young-mature and older mahogany accounted for over $85 \%$ of the population on the Carson and Shoshone Ranges. Mature mahogany accounted for $43 \%$ and $55 \%$ of the Carson and Shoshone populations, respectively. Significantly $(P \leq .05)$ higher densities of overmature mahogany occurred in the Carson Range. This site was the only study area in which overmature mahogany accounted for a substantial portion of the population (19\%).

Greater numbers of young-mature compared to immature mahogany occurred in each study area (Fig. 2). Densities of immature mahogany were lower than those in the reproduction class on the Carson and Shoshone Rangers where mahogany were more dominate. Recruitment of young-mature mahogany into the mature class was also low on these 2 ranges, but not on Peavine Mountain. Many macroplots had larger numbers (Fig. 2) of large mature mahogany over topping fewer and smaller (Tables 3 and 4) youngmature individuals. Frequently these young-mature plants lacked a vigorous canopy and were straggly in appearance.

Recruitment of immature mahogany into the young-mature class apears to be a critical point in the survival of plants as part of the overstory on sites dominated by large individuals. This is also reflected in the long time span that young-mature plants remain in the maturity class. Plants now in the young-mature class may represent a period of plentiful establishment occurring about 350 to $\mathbf{4 0 0}$ years ago possibly following some disturbance.

\section{Mahogany Size}

Largest mahogany were found in the Shoshone Range and the smallest on Peavine Mountain (Tables 3 and 4). Small differences in average mahogany height, average crown diameter, and average crown volume occurred between study areas for reproduction, juvenile, and immature classes, respectively. The young-mature, mature, and overmature classes usually had large differences in average height, average crown diameter, and average crown volume between study areas.

Mature mahogany on all sites had average crown volumes substantially larger than the other maturity classes (Table 4). Differences in average crown volume contribution between mature mahogany and each of the other maturity classes were greatest on the Shoshone Range. There the population structure was strongly skewed towards mature individuals. On Peavine Mountain the mahogany distribution was not skewed towards any one particular maturity class (Fig. 2).

Total mahogany crown volume was substantially greater in the Shoshone Range than in western Nevada (Table 4). Except for Peavine Mountain, mature individuals accounted for well over half of the crown volume. In the Carson and Shoshone Ranges mature mahogany contributed 65 and $90 \%$, of the total crown volume, respectively, but only 45 and $55 \%$ of each population. Overmature mahogany accounted for little crown volume in each study area, and were often similar in size to young-mature plants.

Mahogany encountered in this study were substantially larger than those observed by Duncan (1975) and ranged from smaller to substantially larger than mahogany sampled in Utah (Davis 1976). Dealy (1975) and Davis (1976) found the largest mahogany on dry rocky sites. Our sampling found the largest individuals concentrated on gentle, non-rocky slopes with north and east aspects.

Table 4. Total and average mahogany erown volume $\left(m^{3}\right)$ in each maturity class for 3 mahogany populations in Neveda.

\begin{tabular}{|c|c|c|c|c|c|c|}
\hline \multirow[b]{2}{*}{ Maturity class } & \multicolumn{3}{|c|}{ Total crown volume } & \multicolumn{3}{|c|}{ Average mahogany crown volume } \\
\hline & Peavine Mountain & Carson Range & Shoshone Range & Peavine Mountain & Carson Range & Shoshone Range \\
\hline $\begin{array}{l}\text { Reproduction } \\
\text { Juvenile } \\
\text { Immature } \\
\text { Young-mature } \\
\text { Mature } \\
\text { Overmature } \\
\text { Mean }\end{array}$ & $\begin{array}{r}0.5 \mathrm{a}^{1} \\
5.2 \mathrm{a} \\
32.8 \mathrm{a} \\
296.0 \mathrm{a} \\
309.9 \mathrm{a} \\
79.5 \mathrm{a} \\
723.4 \mathrm{a}\end{array}$ & $\begin{array}{c}-\mathrm{m}^{3} / \text { macroplot- } \\
0.1 \mathrm{a} \\
0.33 \\
0.8 \mathrm{~b} \\
252.3 \mathrm{~b} \\
821.3 \mathrm{a} \\
193.6 \mathrm{a} \\
1248.4 \mathrm{~b}\end{array}$ & $\begin{array}{r}t^{2} \mathrm{ab} \\
0.1 \mathrm{~b} \\
0.9 \mathrm{~b} \\
101.0 \mathrm{c} \\
2063.0 \mathrm{~b} \\
134.0 \mathrm{a} \\
2299.8 \mathrm{~b}\end{array}$ & $\begin{array}{l}t \mathrm{ta} \\
0.2 \mathrm{a} \\
1.0 \mathrm{a} \\
7.5 \mathrm{a} \\
14.6 \mathrm{a} \\
11.2 \mathrm{a} \\
5.8 \mathrm{a}\end{array}$ & $\begin{array}{c}-\mathrm{m}^{3} / \mathrm{plant}- \\
\text { ta } \\
0.2^{3} \\
0.8 \mathrm{a} \\
13.3 \mathrm{~b} \\
29.9 \mathrm{~b} \\
14.5 \mathrm{a} \\
19.7 \mathrm{a}\end{array}$ & $\begin{array}{l}\text { tb } \\
0.1 \mathrm{~b} \\
0.7 \mathrm{a} \\
8.6 \mathrm{ab} \\
66.1 \mathrm{c} \\
34.4 \mathrm{~b} \\
39.5 \mathrm{~b}\end{array}$ \\
\hline
\end{tabular}

IMean values in the same maturity class and within the same crown volume parameter followed by the same letter are not significantly different at the 0.05 level.

zValue is less than 1.1 .

Joo few samples in this study area to calculate t-statistic. 
These were sites that appeared to have greater effective moisture and better growing conditions than the other sites.

Because smaller plants are out-competed by larger ones (Bella 1971, Grace 1985, Weiner 1984), their mortality is higher than that of the larger plants (Westoby 1981). The resulting population structure becomes dominated by a few large individuals, as was the situation in the Carson and Shoshone Ranges (Fig. 2 and Tables 3 and 4). On Peavine Mountain mahogany density has increased substantially during the past 200 years (Fig. 3). Most of the individuals present have not lived long enough to reach the mature class.

\section{Mahozany Ages}

Differences in mean mahogany age (Fig. 2) were only significant $(P \leq 0.05)$ between Peavine Mountain and the Carson and Shoshone Ranges. Mahogany age ranged from 7 to 1,350 years. Maximum ages are substantially older than those determined in previous studies (Dealy 1975, Duncan 1975, Davis 1976, Brotherson et al. 1980). Part of this difference in mahogany age may be due to our technique of enhancing annual ring contrast. We were able to see faint or narrow rings that would have otherwise gone uncounted. Because cross-dating was not possible, some error may be present from false or missing rings.

Ranges in age between the youngest and the oldest mahogany in the same macroplot were as much as 1,000 or more years. It was not uncommon for individuals within the young-mature, mature, and overmature classes, respectively, to have age differences of several hundred years.

Reproduction mahogany in each study area did not have significantly different $(P \leq 0.05)$ ages (Fig. 2) and were classified as reproduction because of their size. It is now apparent that many were not always reproduction, but sometimes suppressed juveniles. Only after the cross sections were aged was it known that mahogany 10 $\mathrm{cm}$ tall can be 30 or more years of age. Schildt and Tisdale (1970) observed a similar situation in Idaho.

Juvenile and older mahogany classes on the Shoshone and Carson Ranges were substantially older than the same maturity classes on Peavine Mountain (Fig. 2). The average age of each maturity class on Peavine Mountain was always older than the preceding maturity class (Fig. 2). In contrast, overmature mahogany in the Carson and Shoshone Ranges were often younger than mature individuals and frequently about the same age as young-mature plants. This indicates many plants in the overmature classes are often severely suppressed individuals that would have otherwise been in the young-mature class.

\section{Relative Plant Growth Rates}

Average ring width for the past 10 years was significantly greater on Peavine Mountain than in the other study areas (Table 5). Each

Table 5. Mean ring width of curlleaf mahogany for the past 10 years in each maturty class for 3 mahogany populations in Nevada.

\begin{tabular}{lccc}
\hline \hline & \multicolumn{3}{c}{ Mean 10 year ring width } \\
\cline { 2 - 4 } $\begin{array}{l}\text { Maturity } \\
\text { Class }\end{array}$ & $\begin{array}{c}\text { Peavine } \\
\text { Mountain }\end{array}$ & $\begin{array}{c}\text { Carson } \\
\text { Range }\end{array}$ & $\begin{array}{c}\text { Shoshone } \\
\text { Range }\end{array}$ \\
\hline & $0.18 \mathrm{~b}$ & $0.09 \mathrm{a}$ & $0.09 \mathrm{a}$ \\
Reproduction & $0.31 \mathrm{a}$ & 0.092 & $0.12 \mathrm{~b}$ \\
Juvenile & $0.36 \mathrm{~b}$ & $0.18 \mathrm{a}$ & $0.14 \mathrm{a}$ \\
Immature & $0.40 \mathrm{~b}$ & $0.16 \mathrm{a}$ & $0.14 \mathrm{a}$ \\
Young-mature & $0.36 \mathrm{~b}$ & $0.15 \mathrm{a}$ & $0.17 \mathrm{a}$ \\
Mature & $0.30 \mathrm{~b}$ & $0.14 \mathrm{a}$ & $0.15 \mathrm{a}$ \\
Overmature & $0.32 \mathrm{~b}$ & $0.14 \mathrm{a}$ & $0.14 \mathrm{a}$ \\
Mean & & & 0.10
\end{tabular}

IMean values in the same maturity class followed by the same letter are not significantly different at the 0.05 level.

2Too few samples in this study area to calculate t-statistic. maturity class on Peavine Mountain also had significantly $(P \leq 0.05)$ greater average ring widths. Both reflect the younger, more open condition of the stands on Peavine Mountain resulting from less dominance by larger, older individuals. These conditions permitted faster growth to occur. A similar pattern exists for average stem area increment (Fig. 3).

Overstory cover in the Carson Range was patchy. Lower relative growth rates on the Carson Range reflected the effect of intraspecific competition in the dense thickets where cover approached $100 \%$.

Reduced growth rates in individual mahogany were common in the Shoshone Range because of the general crown closure (Fig. 4 and Table 5). Average mahogany cover was almost $80 \%$ (Table 2)

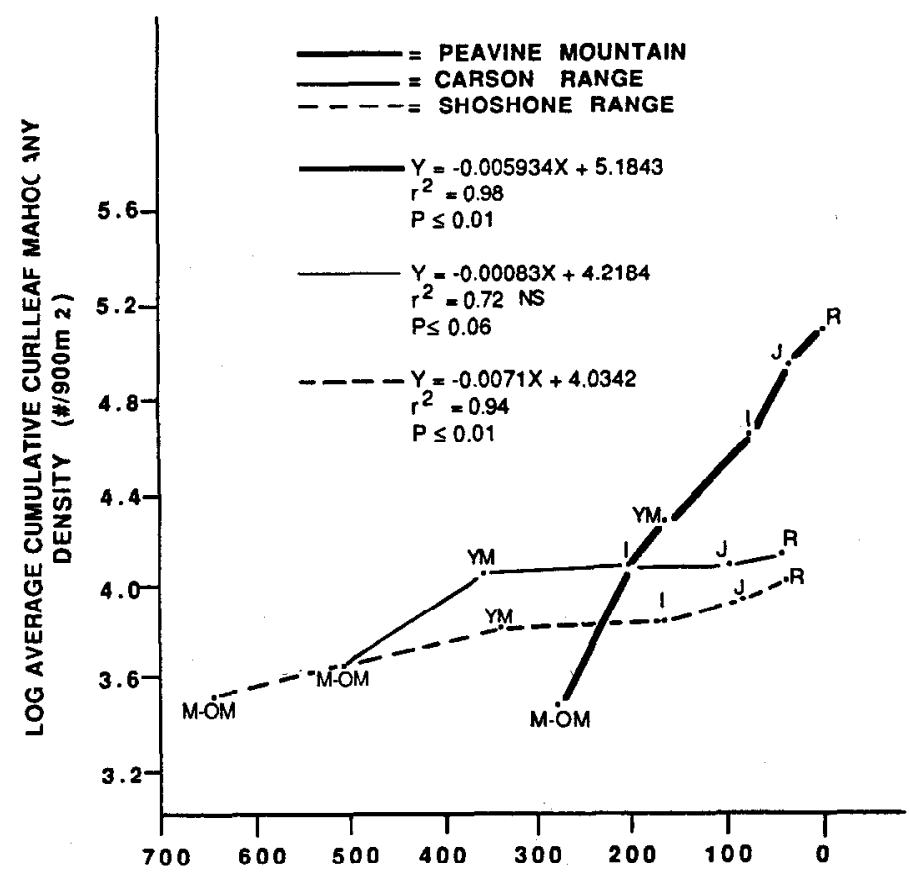

AVERAGE MATURITY ClASS AGE (years)

Fig. 4. Approximate population growth rate curves for curlleaf mahogany at 3 attes in Nevada. Maturity class dedignations of reproduction (R), juvenlle (J), immature (I), young-mature (YM), and mature-overmature (M-OM) are defined in Table 1.

with many macroplots approaching $100 \%$. Relative growth rates in the Shoshone Range were substantially less than those on Peavine Mountain, reflecting the higher average cover. Mahogany populations on most of the sites sampled on the Shoshone Range have probably reached full site occupancy as defined by Long and Smith (1984).

\section{Population Growth Rates}

The slope of a regression line fitted through each population's growth curve (Fig. 4) can be used to provide an estimate of each study area's population growth rate (Harper 1977). The growth rate of the Peavine Mountain population (0.59) was 7 to 8 times greater than that of the Carson Range population (0.08) and the Shoshone Range population (0.07). Regardless of initial density, each population's growth curve appears to have remained relatively constant during the past 300 years.

Recruitment of new individuals into the Shoshone Range and Carson populations has occurred slowly following the establishment of the current mature-overmature mahogany canopy. The estimated time it would take these two populations to double, assuming no mortality, is 1,028 years in the Shoshone Range, and 
900 years in the Carson Range. In contrast, mahogany density on Peavine Mountain has shown a steady increase since the oldest plants were established, and has a doubling time of only 122 years. However, the increases in mahogany populations on Peavine Mountain may have passed their peak. Only 6 plants younger than 20 years were aged, the youngest being 13 years old.

\section{Conclusions}

Self-tolerance, the ability of a species to grow and survive under the stress of intraspecific competition (Zeide 1985), is apparent in curlleaf mahogany communities. Reproduction, juvenile, and immature mahogany have characteristics of tolerant species which can grow for decades under a dense overstory. These small mahogany plants appear to live for 100 or more years as part of the understory (Fig. 2). Self-tolerant species also respond with immediate and rapid growth when the overstory is removed.

Indirect evidence of self-tolerance is present when differences in age (Fig. 2), size (Tables 3 and 4), relative growth rates (Table 5 and Fig. 4) and mahogany cover by maturity class (Fig. 1) are compared. Macroplots on Peavine Mountain had substantially lower mahogany cover values. The immature, juvenile, and reproduction mahogany present, which generally were younger, were slightly larger and faster growing than similar plants in the Shoshone and Carson Ranges. This occurred despite deeper soils and greater annual precipitation in the Carson and Shoshone Ranges.

Curlleaf mahogany is probably an intolerant plant when present with other tree species. Conifers, curlleaf mahogany's most common associate, are often considered intolerant species, but they exhibit growth forms of a species more tolerant than curlleaf mahogany. Relative growth rates are greater, their shape more tapered, and they reach greater heights. Consequently, conifer species invading mahogany sites eventually over top them. Because mature mahogany are shade intolerant their competitive ability is lost, and they become senescent.

In communities dominated by curlleaf mahogany the individuals present do not have to compete with a more tolerant species. Individual plants grow as large as site-specific environmental and genetic constraints allow. However, a small population of selftolerant reproduction plants provide a continuous supply of young mahogany waiting to replace older individuals that dic. Numerous researchers (Denslow 1980, Hartshorn 1980, and Shugart 1984) have noted the importance of canopy gaps in forest succession.

Scheldt and Tisdale (1970) felt that excessive utilization on reproduction mahogany was the cause for poor stand recruitment. Davis (1976) believed that succession was dependent upon habitat factors relating to soil moisture storage and soil development. Dealy (1975) observed rapid and elongated root growth in mahogany seedlings, a characteristic that should improve establishment potential in xeric environments. Our results indicated that abundant mahogany reproduction only occurred where canopy closure did not exist (Peavine Mountain). Deer use on mahogany on Peavine Mountain was as heavy as on the Carson and Shoshone Ranges but the additional stress of intraspecific competition was not present. Young mahogany, particularly if abundant, appear to be able to overcome the stress of herbivory, but not the additive effects of herbivory and intraspecific competition.

Suppressed plants not released from competition eventually die, and are probably replaced by a new wave of reproduction individuals. In essence, two mahogany populations occupy the same stand: one composed of dominant mature plants in the overstory, and the other of suppressed individuals in the understory. Suppressed mahogany slowly recycle awaiting the opportunity for recruitment into the overstory when gaps become available.

\section{Literature Cited}

Assman, E. 1970. The principles of forest yield studies. Studies in the organic production, structure increment, and yield of forest stands. Pergamon Press, Oxford.

Austin, D.D., and P.J. Urneas. 1980. Response of curlleaf mountain mahogany to pruning treatments in northern Utah. J. Range Manage. 33:275-277.

Bella, 1.E. 1971. A new competition model for individual trees. Forest Sci. 17:364-372.

Brotherwon, J.D., J.N. Davis, and L. Greenwood. 1980. Diameter-age relationships of two species of mountain mahogany. J. Range Manage. 33:367-370.

Daubenmire, R.E. 1959. Plants and environment. John Wiley and Son. New York.

Davis, J.B., P.T. Tueller, and A.D. Bruner. 1972. Estimating forage production from shrub ring widths in Hot Creek Valley, Nevada. J. Range Manage. 24:398-402.

Davis, J.N. 1976. Ecological investigations in Cercocarpus ledifolius Nutt. communities of Utah. M.S. Thesis. Brigham Young Univ. Provo, Utah.

Dealy, J.E. 1975. Ecology of curlleaf mahogany (Cercocarpus ledifolius Nutt.) in eastern Oregon and adjacent areas. Ph.D. Diss. Oregon State Univ. Corvallis.

Denslow, J.S. 1980. Gap partitioning among tropical rainforest trees. Biotropica 12(Suppl.):47-55.

Duncan, E. 1975. The ecology of curlleaf mountain mahogany in southwestern Montanta with special reference to mule deer. M.S. Thesis. Montana State Univ. Bozeman.

Grace, J.B. 1985. Juvenile vs adult competitive abilities in plants: sizedependence in cattails (Typha) Ecology 66:1630-1638.

Harper, J.L. 1977. The population biology of plants. Academic Press, New York.

Hartahorn, G.S. 1980. Neotropical forest dynamics. Biotropica 12(Suppl.): 23-30.

Houghton, J.G., C.M. Suknmoto, R.O. Gifford. 1975. Nevada's weather and climate. Spec. Pub. 2. Nevada Bureau of Mines and Geology.

Lon,, J.N., and F.W. Smith. 1984. Relation between size and density in developing stands: a description and possible mechanisms. Forest Ecol. Manage. 7:191-206.

Long, J.N., and J. Turner. 1975. Aboveground biomass of understory and overstory in an age sequence of four Douglas-fir stands. J. Appl. Ecol. 12:179-188.

Ludwig, J.A., J.F. Reynolds, and P.D. Whitson. 1975. Size-biomass relationships in several Chihuahuan Desert shrubs. Amer. Mid. Natur. 94:451-461.

Mitchell, G.E. 1951. Status of browse on ranges of eastern Oregon and eastern Washington. J. Range Manage. 4:249-253.

Ollver, C.D. 1981. Forest development in North America following major disturbances. Forest Ecol. Manage. 3:153-168.

Ormiston, J.H. 1978. Response of curlleaf mountain mahogany to top pruning in southwest Montana. Proc. First Int. Range Cong., Denver, Colo. 1:401-402.

Parker, M.L., G.M. Barton, and J.H.G. Smith. 1976. Annual ring contrast and enhancement without affecting $X$-ray densiometer studies. Tree Ring Bull. 36:29-31.

Phillipa. T. 1970. Summary report of curlleaf mahogany rehabilitation projects in Region 4. USDA Forest Serv. Ogden, Utah. April 22, 1976.

Plummer, A.P. 1974. Morphogenesis and management of woody perennials in the United States, p. 72-80. In: Plant morphogenesis as a basis for scientific management of range resources. Proc. Workshop U.S./Australia Rangelands Panel. Berkeley, Calif. USDA Misc. Pub. 1271.

Sampeon, A.W., and B.S. Jesperaen. 1963. California range brushlands and browse plants. California Agr. Exp. Sta. Ext. Serv. Man. 33.

Scheldt, R.S., and E.W. Tiadale. 1970. Ecology and utilization of curlleaf mountain mahogany in Idaho. Univ. Idaho, Forest. Wildl. and Range Exp. Sta. Note 15.

SCS. 1983. Soil survey of Washoe County Nevada, Southern Part. USDA. Washington, DC.

Shugart, H.H. 1984. A theory of forest dynamics: The ecological implications of forest succession models. Springer-Verlag Inc., New York.

Smith, A.D., and R.L. Hubbard. 1954. Preference ratings for winter deer forages from northern Utah ranges based on browsing time and forage consumed. J. Range Manage. 7:262-265.

Steel, R.G., and J.H. Torrie. 1980. Principles and procedures of statistics. A biometrical approach. McGraw-Hill Book Co., San Francisco, Calif. 
Tausch, R.J. 1980. Allometric analysis of plant growth in woodland communities. Ph.D. Diss. Utah State Univ. Logan.

Thompson, R.M. 1970. Experimental top pruning of curlleaf mountain mahogany trees on the South Horn Mountains, Ferron Ranger District. Manti-Lasal National Forest. USDA Int. Forest and Range Exp. Sta. Range Imp. Note. 15.
Weiner, J. 1984. Neighborhood interference amongst Pinus rigida individuals. J. Ecol. 72:183-196.

Weatoby, M. 1981. The place of the self-thinning rule in population dynamics. Amer. Natur. 118:581-587.

Zeide, B. 1985. Tolerance and self-tolerance of trees. Forest Ecol. Manage. 13:149-166. 